\title{
OPTIMALISASI ENTITAS ECOMMERCE DENGAN MENGGUNAKAN CLOUD MARKETPLACE
}

\author{
Muhammad. Arfan*), Achmad Hidayatno, dan Natalia Putri Ramadhani \\ DepartemenTeknik Elektro, Universitas Diponegoro Semarang \\ J1. Prof. Sudharto, SH, Kampus UNDIP Tembalang, Semarang 50275, Indonesia \\ ${ }^{*}$ E-mail: arfan@ft.undip.ac.id
}

\begin{abstract}
Abstrak
Ecommerce memberikan pengalaman baru dalam transaksi jual beli produk. Kemudahan dalam memilih produk dengan harga bersaing menjadi daya tarik tersendiri bagi pembeli. Perkembangan ecommerce juga memberi solusi bagi pelaku usaha membuka pasar lebih luas dengan penerapan beberapa aplikasi dan layanan yang membantu pelaku usaha dalam mengelola sumber daya bisnis. Di sisi lain, penerapan ecommerce bagi pelaku usaha belum optimal. Hal ini disebabkan aplikasi ecommerce pada umumnya lebih relevan kepada usaha yang memiliki proses bisnis yang mapan dengan modal besar, sehingga pelaku bisnis pemula enggan menggunakan karena proses bisnis yang ditawarkan tidak relevan dan cenderung sulit untuk diterapkan. Ketersediaan SDM dan peralatan pendukung juga menjadi kesulitan tersendiri untuk memulai pengelolaan bisnis berbasis teknologi informasi dan komunikasi. Dari hal tersebut diatas, maka perlu dibangun sistem Cloud Marketplace dengan mengembangkan entitas ecommerce yang sudah ada. Dengan menggunakan sistem Cloud Marketplace, kolaborasi antar pelaku usaha dapat meningkatkan daya saing produk dan calon pembeli lebih mudah dalam menemukan produk berkualitas. Melalui sistem ini pelaku usaha dapat mengelola sumber daya bisnis yang meliputi pengelolaan stok barang, pemasaran dan keuangan. Proses tersebut berjalan online sehingga dapat diakses di mana saja dan kapan saja. Kemudahan akses dan kemudahan penggunaan fitur bisnis yang akan memudahkan pelaku usaha dalam pengelolaan sumber daya bisnis.
\end{abstract}

Kata kunci: ecommerce, cloud marketplace, cloud computing, bisnis online

\begin{abstract}
Ecommerce provides a new experience in buying and selling products. Ease in choosing a competitively priced product to attract buyers. The development of ecommerce also provides solutions for business actors to open a wider market by implementing several applications and services that help business actors in managing business resources. On the other side, the implementation of ecommerce for business actors is not yet optimal. This is because ecommerce applications are generally more relevant to businesses that have established business processes with large capital, so that beginners are reluctant to use because the business processes offered are irrelevant and tend to be difficult to implement. The availability of human resources and supporting equipment is also a difficulty to start business management based on information and communication technology. From the above, it is necessary to build a Cloud Marketplace system by developing an existing ecommerce entity. By using the Cloud Marketplace system, collaboration between business actors can improve the competitiveness of products and prospective buyers easier in finding quality products. Through this system business actors can manage business resources that include stock management, marketing and finance. The process runs online so it can be accessed anywhere and anytime. Ease of access and ease of use of business features that will facilitate business actors in managing business resources.
\end{abstract}

Keywords: ecommerce, cloud marketplace, cloud computing

\section{Pendahuluan}

Ecommerce memberikan pengalaman baru dalam transaksi jual beli produk. Kemunculan beberapa website seperti Zalora, Myntra dan Alibaba sebagai penyedia layanan ecommerce ikut meramaikan persaingan penyajian inovasi layanan berbasis internet. Kemudahan dalam memilih produk dengan harga bersaing menjadi daya tarik tersendiri bagi pembeli.

Menurut data Kementerian Koperasi dan UKM, jumlah Usaha Kecil Menengah (UKM) hingga tahun 2013 mencapai sekitar 57,8 juta. Di sisi lain, berdasarkan 
sensus ekonomi Badan Pusat Statistik tahun 2016 dalam kurun waktu 10 tahun mengalami pertumbuhan 17 persen dengan jumlah ecommerce di Indonesia mencapai 26,2 juta. Potensi pengembangan pasar bagi produk UKM masih terbuka luas tapi tidak didukung implementasi teknologi infomasi yang optimal. Hal ini disebabkan aplikasi ecommerce pada umumnya lebih relevan kepada usaha yang memiliki proses bisnis yang mapan dengan modal besar, sehingga pelaku bisnis pemula enggan menggunakan karena proses bisnis yang ditawarkan tidak relevan dan cenderung sulit untuk diterapkan.[1]

Dari hal tersebut diatas, maka perlu dibangun sistem Cloud Marketplace dengan mengembangkan entitas ecommerce yang sudah ada [2].Dengan menggunakan sistem Cloud Marketplace, kolaborasi antar pelaku usaha dapat meningkatkan daya saing produk dan calon pembeli lebih mudah dalam menemukan produk berkualitas. Melalui sistem ini pelaku usaha dapat mengelola sumber daya bisnis yang meliputi pengelolaan stok barang, pemasaran dan keuangan. Proses tersebut berjalan online sehingga dapat diakses di mana saja dan kapan saja. Kemudahan akses dan kemudahan penggunaan fitur bisnis yang akan memudahkan pelaku usaha dalam pengelolaan sumber daya bisnis dan pemasaran produk.

\section{Metode}

\subsection{Cloud Computing}

Cloud computing merupakan model yang menawarkan kemudahan akses jaringan on-demand ke dalam portal bagi pakai dengan menggunakan sumber daya komputasi yang dapat dikelola (jaringan, server, penyimpanan, aplikasi, dan layanan) yang dapat diakses dengan cepat mudah untuk mengolah dan berinteraksi dengan penyedia layanan. [3]

Sedangkan tiga jenis model layanan dijelaskan oleh NIST (Mell dan Grance, 2009) sebagai berikut :

1. Software as a Service (SaaS)

Bentuk layanan yang diberikan kepada konsumen untuk menggunakan aplikasi yang dapat beroperasi pada infrastruktur cloud. Aplikasi dapat diakses dari berbagai perangkat klien melalui antarmuka seperti web browser (misalnya, Yahoomail, Dropbox, Google Docs). Konsumen tidak mengelola atau mengendalikan infrastruktur cloud yang mendasar termasuk jaringan, server, sistem operasi, penyimpanan.

2. Platform as a Service (PaaS)

Bentuk layanan yang diberikan kepada konsumen untuk menyebarkan aplikasi yang dibuat konsumen dengan menggunakan teknik pemrograman dan peralatan yang didukung oleh provider. Konsumen tidak mengelola atau mengendalikan infrastruktur cloud yang mendasar termasuk jaringan, server, sistem operasi, atau penyimpanan, namun memiliki kontrol atas aplikasi disebarkan. Contoh : Android (Google Playstore), Facebook.com (layanan aplikasi dan game yang online) 3. Infrastructure as a Service (IaaS)
Bentuk layanan yang diberikan kepada konsumen untuk memproses, menyimpan, dan komputasi dasar yang penting. Dimana konsumen dapat menyebarkan dan menjalankan perangkat lunak secara bebas mencakup sistem operasi dan aplikasi. Konsumen tidak mengelola atau mengendalikan infrastruktur cloud yang mendasar tetapi memiliki kontrol atas sistem operasi, penyimpanan, aplikasi yang disebarkan tetapi dibatasi komponen jaringan yang pilih (misalnya, firewall host).[4]

\subsection{Ecommerce}

Ecommerce merupakan suatu proses membeli dan menjual produk-produk secara elektronik oleh konsumen dan dari perusahaan ke perusahaan dengan komputer sebagai perantara transaksi bisnis. [5]

Ecommerce atau yang biasa disebut juga dengan istilah Ecom atau Emmerce atau EC merupakan pertukaran bisnis yang rutin dengan menggunakan transmisi Electronic Data Interchange (EDI), email, electronic bulletin boards, mesin faksimili, dan Electronic Funds Transfer yang berkenaan dengan transaksi-transaksi belanja di Internet shopping.[1]

Ecommerce dapat ditinjau dalam 4 perspektif berikut :[6]

1. Perspektif komunikasi adalah pengiriman barang, layanan, informasi, atau pembayaran melalui jaringan komputer atau melalui peralatan elektronik lainnya.

2. Perspektif proses bisnis adalah aplikasi dari teknologi yang menuju otomatisasi dari transaksi bisnis dan aliran kerja.

3. Perspektif layanan merupakan suatu alat yang memenuhi keinginan perusahaan, konsumen, dan manajemen untuk memangkas biaya layanan (service cost) ketika meningkatkan kualitas barang dan meningkatkan kecepatan layanan pengiriman.

4. Perspektif online dengan menyediakan kemampuan untuk membeli dan menjual barang ataupun informasi melalui internet dan sarana online lainnya.[5]

Industri teknologi informasi melihat kegiatan e-commerce ini sebagai aplikasi dan penerapan dari e-bisnis (ebusiness) yang berkaitan dengan transaksi komersial, seperti: transfer dana secara elektronik, SCM (supply chain management), pemasaran elektronik (e-marketing), atau pemasaran online (online marketing), pemrosesan transaksi online (online transaction processing), pertukaran data elektronik (electronic data interchange /EDI), dll.

Ecommerce merupakan bagian dari e-business, di mana cakupan e-business lebih luas, tidak hanya sekadar perniagaan tetapi mencakup juga pengkolaborasian mitra bisnis, serta pelayanan nasabah.[7]

\section{Hasil dan Analisa}

\subsection{Infrastruktur Cloud Marketplace}

Cloud Marketplace dibangun dengan menggunakan dua unit server dengan teknik virtualisasi. Mesin server basis 
data dan sistem backup akan diimplementasikan dalam satu server yang telah dibenamkan sistem operasi yang mendukung Kernel-based Virtual Machine (KVM) untuk virtualisasi mesin server dan satu unit yang lain sebagai web server menangani aplikasi berbasis web. Dapat dijabarkan sebagai berikut:

1. Virtual Machines sebagai platform menggunakan proxmox dan diatasnya berdiri sistem operasi berbasis linux yang masing-masing dipasang aplikasi MySQL.

2. Web Server sebagai mesin aplikasi berbasis web menggunakan sistem operasi linux yang dipasang aplikasi web server seperti Apache, PHP dan panel control menggunakan EHCP.

3. Web Portal sebagai aplikasi utama untuk costumer, Pengelola dan Reseler

Penggunaan Virtual Machine(VM) pada Cloud Infrastucture akan menghemat sumber daya server dan mempunyai dasar logika yang menggunakan pendekatan lapisan dari sistem komputer, sehingga sistem komputer dapat dibangun diatas lapisan-lapisan tersebut, dengan urutan lapisannya mulai dari lapisan terendah sampai lapisan teratas. Dengan teknologi ini pengguna sistem tidak perlu menyiapkan banyak server tetapi hanya satu mesin dengan banyak fungsi server. Semua transaksi data akan diolah cloud marketplace server dan hasilnya dapat dilaporkan secara realtime.

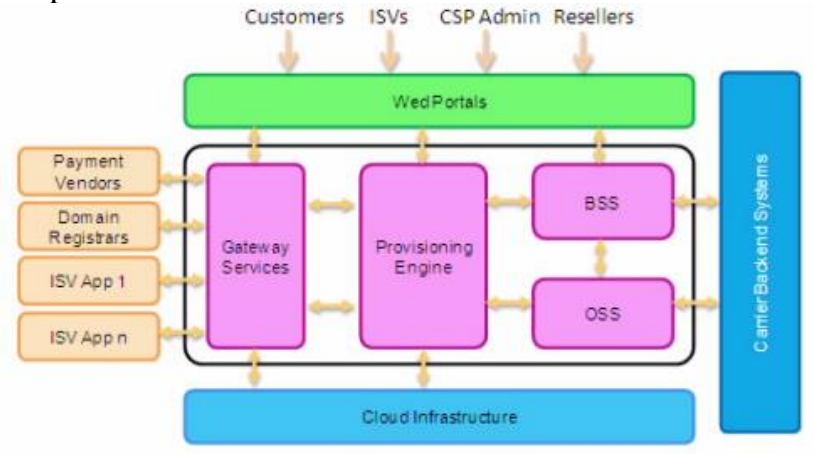

\section{Gambar 1. Cloud Marketplace Infrastructure}

Pengguna akan menggunakan sebuah portal sebagai gerbang untuk masuk ke dalam layanan Cloud
Marketplace. Dalam portal tersebut akan dilakukan proses otentikasi bagi pelaku usaha baik vendor (pemasok) maupun reseler yang dimana jika berhasil maka pengguna akan diarahkan menu utama.

Proses optimalisasi entitas dilakukan dengan menganalisis proses yang terlibat, terdiri dari :

1.Pembelian, proses untuk menginputkan transaksi penjualan yang mana pada proses ini terdapat data supplier, data barang, dan data administrasi. Data penjualan ini menjadi pusat referensi data semua transaksi penjualan yang terjadi.

2. Penyimpanan Barang, proses untuk melakukan penyimpanan barang ke gudang yang mana proses ini terdapat: data gudang, data barang.

3. Penjualan, proses ini merupakan proses untuk menginputkan transaksi penjualan yang mana pada proses ini terdapat data custumer, data barang, dan data administrasi. Data penjualan ini menjadi pusat referensi data semua transaksi penjualan yang terjadi.

4. Keuangan, proses ini merupakan proses untuk melakukan pembukuan dari semua transaksi, proses ini terdiri dari data keuangan, data nota beli, nota jual,. Dari proses ini akan menghasilkan laporan-laporan seperti laporan kas kecil, laporan buku besar, laporan buku bank, laporan rugi laba.

\subsection{Desain Sistem}

Cloud Marketplace. Dalam portal tersebut akan dilakukan proses otentikasi bagi pelaku usaha baik vendor (pemasok) maupun reseler yang dimana jika berhasil maka pengguna akan diarahkan menu utama.

Pengguna akan menggunakan sebuah portal sebagai gerbang untuk masuk ke dalam layanan Cloud. Dalam portal tersebut akan dilakukan proses otentikasi yang dimana jika berhasil maka pengguna akan diarahkan menu utama.Dalam merancang sistem, digunakan alat berupa Data Flow Diagram (DFD). Proses DFD yang pertama dimulai dari penggambaran level konteks diagram seperti terlihat pada gambar berikut .[8] 
TRANSIENT, VOL. 7, NO. 1, MARET 2018, ISSN: 2302-9927, 212

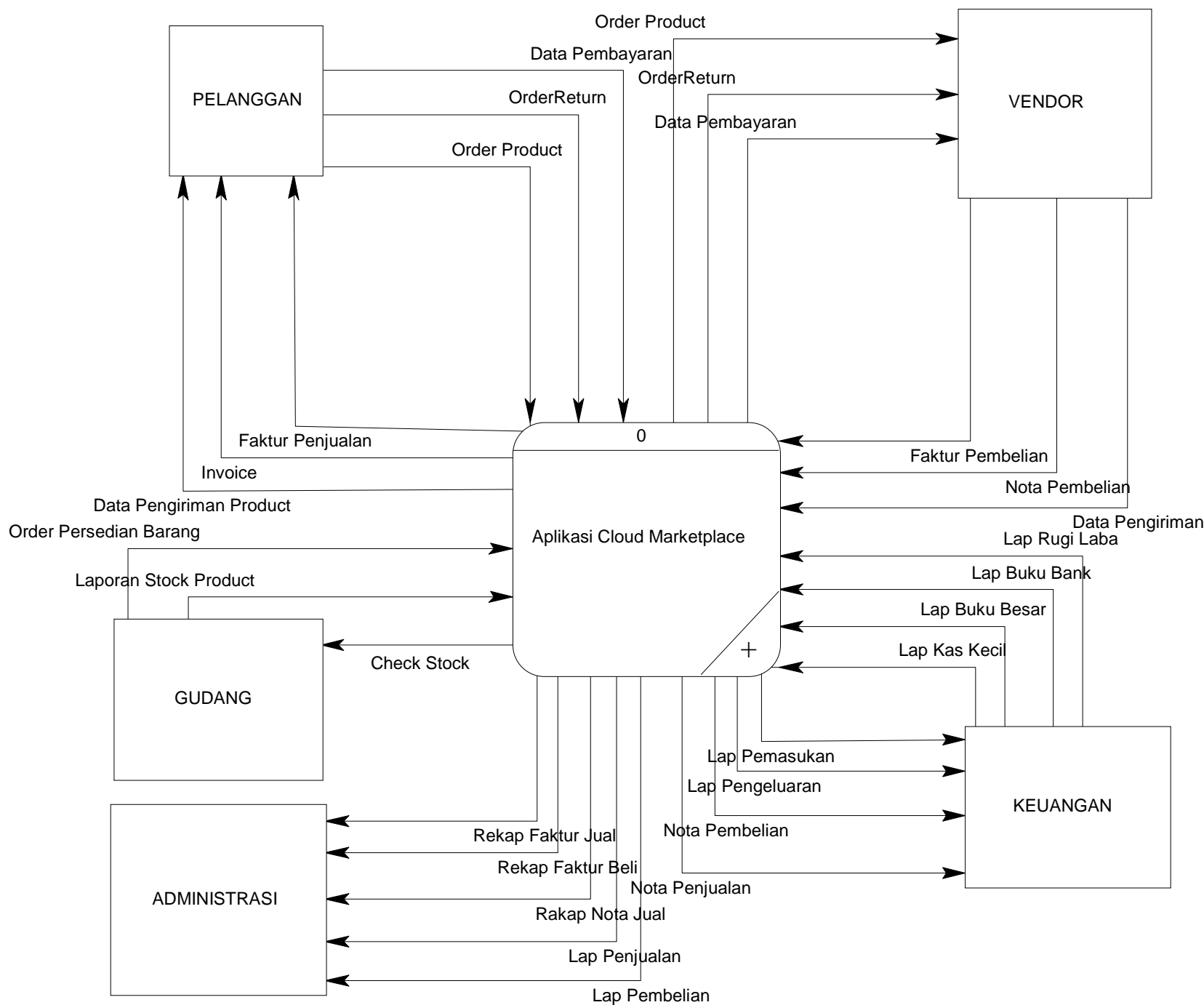

Gambar 2. Diagram Konteks Cloud Marketplace

Proses pembelian merupakan proses untuk menginputkan transaksi penjualan dan terdapat data supplier, data barang, dan data administrasi. Data penjualan ini menjadi pusat referensi data semua transaksi penjualan yang terjadi. Penyimpanan Barang merupakan proses untuk melakukan penyimpanan barang ke gudang yang mana proses ini terdapat : data gudang, data barang. Proses penjualan merupakan proses untuk menginputkan transaksi penjualan yang mana pada proses ini terdapat data custumer, data barang, dan data administrasi. Data penjualan ini menjadi pusat referensi data semua transaksi penjualan yang terjadi. Bagian keuangan merupakan proses untuk melakukan pembukuan dari semua transaksi, proses ini terdiri dari data keuangan, data nota beli, nota jual,. Dari proses ini akan menghasilkan laporan-laporan seperti laporan kas kecil, laporan buku besar, laporan buku bank, laporan rugi laba.

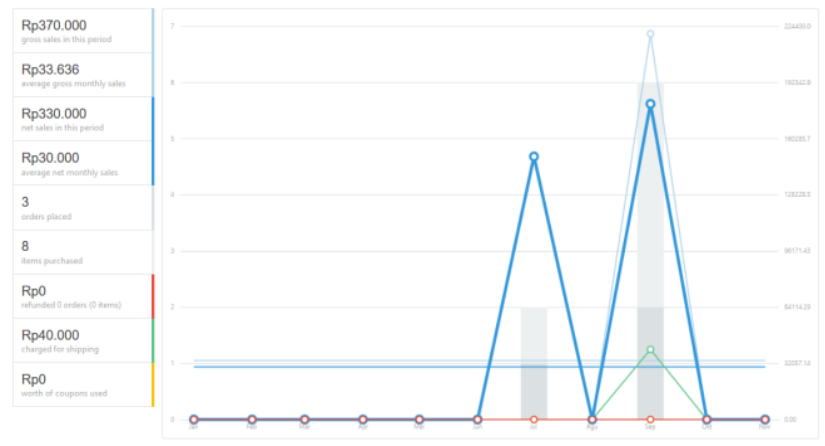

Gambar 3. Laporan Penjualan

Untuk mendukung proses bisnis maka sistem menyediakan beberapa fitur, terdiri dari fitur pemasukan, untuk segala macam pemasukan, fitur arus kas untuk pencatatan saldo, fitur rantai pasok untuk informasi arus stok barang dari para penyedia barang, fiitur Inventaris barang dan fitur laporan laba rugi, berfungsi untuk membantu dan mengetahui jumlah keuntungan bagi 
pengguna yang tegabung cloud marketplace ini. Dengan sistem ini pengelola dan pelanggan mendapatkan keuntungan.

\section{Kesimpulan}

Optimalisasi entitas ecommerce dapat dilakukan dengan melakukan observasi kebutuhan komunitas pelaku usaha. Penyajian teknologi dibuat dengan fitur kemudahan navigasi untuk memudahkan pengguna dan antar muka aplikasi bisa menyesuaikan perangkat yang digunakan sehingga bisa diakses oleh perangkat gawai apapun. Kelengkapan fitur akan bekontribusi pada beban pada server sehingga dibutuhkan penggunaan teknik pemrograman untuk memecah program menjadi beberapa fungsi yang moduler

\section{Referensi}

[1] K. C. Laudon and C. G. Traver, E-Commerce 2017. 2014.

[2] Z. A. Mohammed and G. P. Tejay, "Examining privacy concerns and ecommerce adoption in developing countries: The impact of culture in shaping individuals' perceptions toward technology," Comput. Secur., vol. 67, pp. 254-265, 2017.

[3] P. M. Mell and T. Grance, "The NIST definition of cloud computing," 2011.

[4] A. Boukerche and R. E. De Grande, "Vehicular cloud computing: Architectures, applications, and mobility," Comput. Networks, vol. 135, pp. 171-189, 2018.

[5] Z. F. Yang, Y. Shi, B. Wang, and H. Yan, "Website quality and profitability evaluation in ecommerce firms using two-stage DEA model," Procedia Comput. Sci., vol. 30, pp. 4-13, 2014.

[6] R. Kalakota and A. B. Whinston, Electronic Commerce:, vol. 39, no. 6. 1997.

[7] R. Y. K. Lau, "Towards a web services and intelligent agents-based negotiation system for B2B eCommerce," Electron. Commer. Res. Appl., vol. 6, no. 3, pp. 260273, 2007.

[8] P. R. Kumar, P. H. Raj, and P. Jelciana, "Exploring Data Security Issues and Solutions in Cloud Computing," Procedia Comput. Sci., vol. 125, no. 2009, pp. 691-697, 2018. 